\title{
Penerapan Layanan Karier Untuk Meningkatkan Kematangan Karier Siswa SMK PGRI Wonoasri Kabupaten Madiun
}

\author{
1) Bernardus Widodo, ${ }^{2)}$ Chaterina Yeni Susilaningsih
}

1), 2) Dosen Prodi Bimbingan dan Konseling Universitas Katolik Widya Mandala Surabaya, Kampus Kota Madiun E-mail: cyenisusilaningsih@gmail.com

\begin{tabular}{|c|c|}
\hline Article Info & Abstract \\
\hline Article History & The research objectives (1) Knowing the career maturity level of the students of SMK \\
\hline Received: $2020-11-17$ & PGRI Wonoasri Madiun Regency in the 2018-2019 academic year, (2) Knowing the \\
\hline $\begin{array}{l}\text { Revised: 2021-01-05 } \\
\text { Published: 2021-01-13 }\end{array}$ & extent to which the application of career services can improve the career maturity of \\
\hline & the XII grade students of SMK PGRI Wonoasri Madiun Regency. This study uses the One \\
\hline & Group Pretest - Posttest Design pattern. The research population was students of class \\
\hline Keywords: & XII Accounting at SMK PGRI Wonoasri Madiun Regency in the 2018 - 2019 academic \\
\hline Kematangan; & year, totaling 49 people. The research sample was determined using purposive \\
\hline Karier; & sampling technique. The data collection instrument used documentation study through \\
\hline & the provision of career material and career group counseling with the following stages: \\
\hline & 1) the formation stage, 2) the transitional stage, 3 ) the activity stage, 4) the termination \\
\hline & $\begin{array}{l}\text { stage, and a career maturity questionnaire. Analysis of research data using the t-Test } \\
\text { build formula. The results show that the mean score before being given intervention }\end{array}$ \\
\hline & $\begin{array}{l}\text { through the application of career services is } 85.60 \text {, and the mean score after being } \\
\text { given the application of career services is } 88.90 \text {, so it can be concluded that there is an }\end{array}$ \\
\hline & increase in the level of student career maturity through the application of career \\
\hline & services. The conclusions in this study are 1) there is an increase in student career \\
\hline & $\begin{array}{l}\text { maturity through the application of career services amounting to } 3.30 \% \text {. This can be } \\
\text { seen from the mean score before treatment is } 85.60 \text { and after treatment is } 88.90,2 \text { ) the }\end{array}$ \\
\hline & $\begin{array}{l}\text { application of career services is effective in increasing the career maturity of students } \\
\text { of SMK PGRI Wonoasri, Madiun Regency. }\end{array}$ \\
\hline
\end{tabular}

\begin{tabular}{l}
\hline Artikel Info \\
\hline Sejarah Artikel \\
Diterima: $2020-11-17$ \\
Direvisi: 2021-01-05 \\
Dipublikasi: $2021-01-13$
\end{tabular}

Kata kunci: Kematangan;

Karier;

Layanan.

\begin{abstract}
Abstrak
Tujuan penelitian (1) Mengetahui tingkat kematangan karier siswa SMK PGRI Wonoasri Kabupaten Madiun tahun pelajaran 2018 - 2019, (2) Mengetahui sejauh mana penerapan layanan karir dapat meningkatkan kematangan karier siswa kelas XII SMK PGRI Wonoasri Kabupaten Madiun. Penelitian ini menggunakan pola One Group Pretest - Posttest Design. Populasi penelitian adalah siswa kelas XII Akuntansi SMK PGRI Wonoasri Kabupaten Madiun pada tahun pelajaran 2018 - 2019 yang berjumlah 49 orang. Sampel penelitian ditetapkan dengan menggunakan teknik purposive sampling. Instrumen pengumpulan data menggunakan studi dokumentasi melalui pemberian materi karier dan konseling kelompok karier dengan tahapan sebagai berikut: 1) tahap pembentukan, 2) tahap peralihan, 3) tahap kegiatan, 4) tahap pengakhiran, dan angket kematangan karier. Analisis data penelitian menggunakan rumus bangun t-Test. Hasil penelitian diketahui skor mean sebelum diberikan intervensi melalui penerapan layanan karier sejumlah 85,60, dan skor mean setelah diberikan penerapan layanan karier menjadi 88,90, sehingga dapat disimpulkan terjadi peningkatan tingkat kematangan karier siswa melalui penerapan layanan karier. Simpulan dalam penelitian ini adalah 1) adanya peningkatan kematangan karier siswa melalui penerapan layanan karier sejumlah 3,30 \%. Hal ini dapat diketahui dari skor mean sebelum diberikan perlakuan sejumlah 85,60 dan sesudah diberikan perlakuan sejumlah $88,90,2$ ) penerapan layanan karier efektif dalam meningkatkan kematangan karier siswa SMK PGRI Wonoasri Kabupaten Madiun.
\end{abstract}

\section{PENDAHULUAN}

Mempunyai karir yang baik merupakan dambaan setiap individu. Melalui karier yang dimiliki, seseorang dapat mengekspresikan dirinya kearah yang diinginkannya. Karier dapat dicapai melalui usaha, kerja keras dan motivasi yang kuat dari seseorang dan dapat diaplikasikan dalam pekerjaaannya. Melalui bekerja seseorang dapat memperoleh kepuasan, seperti upah yang layak, penghargaan dan prestasi, salah satunya yaitu karir yang telah berhasil diraihnya. 
Menurut Hornby (dalam Walgito, 2010: 201) karir adalah pekerjaan atau profesi. Pekerjaan akan dilakukan dengan senang hati dan penuh kegembiraan apabila apa yang dilakukan sesuai dengan keadaaan dirinya, kemampuannya, minatnya dan potensi-potensi yang ada pada dirinya. Sehingga orang yang menduduki karir tersebut akan berusaha meningkatkan prestasinya, mengembangkan potensi dirinya, lingkungannya, serta sarana dan prasarana yang diperlukan dalam menunjang perkerjaan yang sedang dijabatnya. Sebaliknya individu tidak akan merasa nyaman apabila pekerjaan yang dilakukannya tidak sesuai dengan dirinya.

Remaja berada pada masa transisi seringkali kesulitan dalam menentukan pilihan kariernya. Menurut Super (dalam Suherman, 2013: 78) perkembangan karier remaja berada pada tahap eksplorasi (usia 15-24 tahun), yang ditandai dengan mulai melakukan penelaahan diri, mencoba membagi berbagai peranan, serta melakukan penjelajahan pekerjaan. Siswa SMK memang difokuskan dengan lulusan yang siap kerja, walaupun pada kenyataannya banyak siswa yang sanggup untuk melanjutkan pendidikan ke jenjang berikutnya yaitu kuliah, akan tetapi siswa SMK cenderung memilih untuk bekerja, walaupun dengan kondisi pekerjaan yang kurang memadai, baik dari segi finansial maupun kelayakan dalam bekerja. Fenomena yang terjadi di SMK PGRI Wonoasri Kabupaten Madiun, khususnya siswa kelas XII hampir $90 \%$ memilih untuk bekerja daripada melanjutkan kuliah walaupun secara ekonomi dan kemampuan sebenarnya mencukupi. Pernyataan tersebut diperoleh dari hasil wawancara dengan Guru BK pada tanggal 16 Februari 2019 dan informasi dari siswa kelas XII pada waktu promosi yang dilakukan oleh Universitas Katolik Widya Mandala Madiun pada tanggal 9 November 2018. Permasalahan yang terjadi hampir 90\% siswa memilih untuk bekerja seadanya seperti di pabrik, toko dan menjadi TKW daripada melanjutkan studi ke jenjang selanjutnya atau kuliah, walaupun secara ekonomi dan kemampuan sebagian siswa dapat melakukannya. Hal ini dikarenakan banyaknya lowongan pekerjaan di pabrik, menjadi TKW dan penjaga toko di luar kota, dan sebagian siswa mengikuti teman yang sebelumnya sudah bekerja. Sebenarnya hal ini sangat disayangkan, untuk itu perlu dicarikan solusi, yaitu salah satunya melalui layanan karier yang diberikan di sekolah, dalam hal ini layanan karier yang diberikan yaitu layanan klasikal dan konseling karier.

Menurut Muro dan Kottman (dalam Suherman, 2013: 79) dalam pengembangan karier siswa (remaja) di sekolah menengah sangat diperlukan kesadaran diri untuk mulai melakukan eksplorasi dan orientasi karier yang lebih formal. Hal ini dapat dilakukan salah satunya melalui layanan karier yang diselenggarakan di sekolah secara efektif. Layanan karier yang dilakukan di sekolah diaplikasikan dalam wadah bimbingan karier. Bimbingan karier dalam membantu meningkatkan kematangan karier siswa diberikan melalui berbagai cara dan bentuk layanan antara lain layanan klasikal dan konseling kelompok. Menurut Nurihsan (2005: 45) berdasarkan fungsi dan prinsip bimbingan bahwa rangka kerja layanan BK yang dijabarkan dalam empat kegiatan utama yaitu: 1) layanan dasar bimbingan,, 2) layanan responsif, 3) layanan perencanaan individual, dan 4) dukungan sistem. Dari keempat komponen bimbingan dan konseling yang sesuai untuk meningkatkan kematangan karier yaitu layanan responsif dan perencanaan individual, dalam penelitian ini menggunakan layanan konseling kelompok dan layanan klasikal.

Melalui layanan karir diharapkan siswa dapat menyadari kemampuannya dan dapat meningkatkan pemahaman tentang perencanaan kariernya sehingga dapat meningkatkan kematangan kariernya. Bertolak dari uraian pada latar belakang di atas, maka dikemukakan rumusan masalah sebagai berikut:

1) Bagaimana tingkat kematangan karier siswa kelas XII di SMK PGRI Wonoasri Kabupaten Madiun tahun pelajaran 2018 - 2019?, 2) Apakah penerapan layanan karier dapat meningkatkan kematangan karir siswa di SMK PGRI Wonoasri Kabupaten Madiun tahun pelajaran 2018-2019?, Dengan tujuan yang ditetapkan sebagai berikut: 1) Mengetahui tingkat kematangan karier siswa SMK PGRI Wonoasri Kabupaten Madiun tahun pelajaran 2018 - 2019, 2) Mengetahui sejauh mana penerapan layanan karier dapat meningkatkan kematangan karier siswa SMK PGRI Wonoasri Kabupaten Madiun tahun pelajaran 2018 - 2019.

\section{A. Layanan Karier}

1) Pengertian Layanan

Pelayanan merupakan aspek yang tidak bisa dipisahkan dalam pelaksanaan bimbingan karier, yang dilakukan oleh seorang konselor kepada konseli atau siswa. Dalam pemberian layanan tersebut dengan tujuan untuk membantu siswa memenuhi kebutuhannya. Menurut Poerwadarminto (dalam KUBI, 1996: 245) pengertian pelayanan atau layanan adalah menolong menyediakan segala apa yang dibutuhkan orang lain.

2) Pengertian Karier

Menurut Tilgher (dalam Suherman 2013: 19) karier adalah perjalanan yang dilalui seseorang selama hidupnya. Sedangkan menurut Super (dalam Sukardi, 1987: 17) karier merupakan suatu rangkaian pekerjaanpekerjaan, jabatan-jabatan dan kedudukan yang mengarah pada kehidupan dalam dunia kerja.

Karier dapat dikategorikan dalam dua bagian, yaitu karier yang identik dengan dunia pekerjaan, dan karier dalam konteks life span yaitu karier yang dimaknai sebagai perjalanan hidup individu yang bermakna, seperti peran atau peristiwa yang melibatkan pengambilan keputusan- keputusan, komitmen, gaya hidup, dedikasi, dan persiapan-persiapan untuk menjalani dan mengakhiri kehidupan. Dalam 
hal ini karir merupakan manifestasi dari hidup dan kehidupan itu sendiri. Karir juga dapat digunakan untuk menyebutkan orang-orang pada tiap-tiap peran atau status. Dan karir juga merupakan seluruh jabatan (pekerjaan) yang mempunyai tanggung jawab individu (Ekaningrum, 2002: 258).

Dari definisi tentang karier di atas, maka dapat disimpulkan pengertian karier adalah jalannya kehidupan dalam rangkaian-rangkaian pekerjaan dan tanggung jawab seseorang di dalam dunia kerjanya. Sedangkan layanan karier adalah suatu bantuan yang diberikan konselor kepada siswa uagar dapat merencanakan, mengeksplor dan mengambil keputusan kariernya sesuai potensi dan kemampuannya.

\section{B. Kematangan Karier}

1) Pengertian Kematangan Karier

Criter (dalam Suherman, 2013: 81) menekankan kematangan karier sebagai tahapan hidup (life stages) atau kesiapan individu untuk membuat pilihan dan keputusan karier yang tepat. Sedangkan menurut Super (dalam Winkel dan Sri, 2006: 633) menyebutkan bahwa kematangan karier merupakan keberhasilan individu dalam menyelesaikan tugas perkembangan karier yang khas di setiap tahap perkembangan yang ditunjukkan dengan kesesuaian perilaku karier individu dengan perilaku karier yang diharapkan. Menurut Brown (dalam Atli, 2017) kematangan karier adalah seperangkat sifat emosional dan kognitif, termasuk keterampilan untuk menangani situasi mengenai pilihan karier.

Dijelaskan pula oleh Savickas 1984 (dalam Patton, 2002) Kematangan karier secara luas mengacu pada kesiapan individu untuk membuat keputusan karier yang tepat berdasarkan usia dan mengatasi tugas pengembangan karier. Definisi mencakup kemampuan individu untuk membuat pilihan karier yang tepat, termasuk kesadaran tentang apa yang diperlukan untuk membuat keputusan karier dan sejauh mana pilihan seseorang realistis dan konsisten.

Berdasarkan pendapat para ahli di atas, maka dapat disimpulkan kematangan karier adalah kesiapan individu merencanakan dan menentukan keputusan kariernya berdasarkan kemampuan dan tugas perkembangannya masing-masing.

2) Indikator-indikator Kematangan Karier

Berdasarkan uraian di atas maka dapat dikatakan bahwa kematangan remaja dapat diukur dengan dimilikinya indikator-indikator atau aspek-aspek kematangan karier sebagai berikut, seperti yang disampaikan oleh Super (dalam Suherman, 2013: 82), antara lain: a)
Aspek Perencanaan Karier (Career Planning), Individu yang dapat mempelajari informasi karir, membicarakan karier dengan orang dewasa, mengikuti pendidikan tambahan (kursus), mengikuti pelatihan-pelatihan berkaitan dengan pekerjaan yang diinginkan, mengetahui kondisi pekerjaan yang diinginkan, merencanakan apa yang harus dilakukan setelah tamat sekolah, dan mengetahui cara dan kesempatan memasuki dunia kerja yang diinginkan. b) Aspek Eksplorasi Karier (Career Exploration), Individu dapat menggali dan mencari informasi karier dari berbagai sumber, memiliki pengetahuan tentang potensi diri (bakat, minat, intelegensi, kepribadian, dan prestasi), memiliki cukup banyak informasi karier. c) Aspek tentang pengetahuan dalam membuat keputusan karier (Decision Making), yaitu: mengetahui cara-cara membuat keputusan karier dan menggunakan pengetahuan dan pemikiran dalam membuat keputusan karier. d) Aspek pengetahuan tentang dunia kerja (World of Work Information), Konsep ini memiliki dua komponen dasar, yaitu berhubungan dengan tugas perkembangan untuk mengetahui minat dan kemampuan dirinya, dan konsep yang berkaitan dengan pengetahuan tentang tugastugas pekerjaan dalam satu vokasional dan perilaku dalam bekerja. e) Aspek pengetahuan tentang kelompok pekerjaan yang lebih disukai (Knowledge of preferred occupational group), meliputi: (1) Mengetahui persyaratan fisik dan psikologis dari pekerjaan yang diinginkan (2) Mengetahui minat-minat dan alasan yang tepat dalam memilih pekerjaan. f) Aspek Realisme Keputusan Karier (Realism), Realisme keputusan karier adalah perbandingan antara kemampuan individu dengan pilihan pekerjaan secara realistis. g) Aspek Orientasi Karier (Career Orientation), meliputi: (1) Sikap terhadap karier, (2) Keterampilan membuat keputusan karier, (3) Informasi dunia kerja. (Suherman, 2013: 82)

\section{Faktor-faktor Yang Mempengaruhi Perkembangan Karier}

Menurut Shertzer dan Stone (1981) (Winkel, 2006: 647) terdapat beberapa faktor yang berpengaruh terhadap perkembangan karier seseorang, antara lain: a) Faktor Internal, yang dimaksud dengan faktor internal adalah faktorfaktor yang terkait dengan diri individu itu sendiri. Faktor-faktor yang terkait tersebut antara lain: (1) Nilai-nilai kehidupan (values) Yaitu sesuatu yang ideal yang dikejar oleh seseorang. Nilai-nilai menjadi pedoman dan pegangan dalam hidup sampai umur tuadan sangat menentukan bagi gaya hidup seseorang. (2) Taraf Inteligensi Yaitu taraf kemampuan untuk mencapai prestasi-prestasi yang yang didalamnya berpikir memegang peranan. (3) Bakat khusus Yaitu kemampuan yang 
menonjol di suatu bidang usaha kognitif, bidang keterampilan, atau bidang kesenian. Suatu bakat khusus menjadi bekal yang memungkinkan untuk memasuki berbagai bidang pekerjaan tertentu. (4) Minat Yaitu Kecenderungan yang agak menetap pada seseorang untuk merasa tertarik pada satu bidang tertentu dan merasa senang berkecimpung dalam berbagai kegiatan yang berkaitan dengan bidang itu. (5) Sifat-sifat Yaitu ciri-ciri kepribadian yang bersama-sama memberikan corak khas pada seseorang, seperti sifat riang, gembira, ramah, teliti. Pada umumnya diakui bahwa orang tersebut akan kurang cocok untuk memegang suatu jabatan tertentu. (6) Pengetahuan Yaitu informasi yang dimiliki tentang bidang-bidang pekerjaan dan tentang diri sendiri. (7) Keadaan Jasmani Yaitu ciri-ciri fisik yang dimiliki seseorang seperti tinggi badan, tampan, cantik, mempunyai pendengaran yang baik, dan jenis kelamin. b) Faktor-faktor Eksternal, Faktor eksternal terkait dengan masyarakat, keadaan sosial ekonomi, status sosial ekonomi keluarga, pengaruh dari seluruh anggota keluarga besar dan keluarga inti, pendidikan sekolah, pergaulan dengan teman sebaya, dan tuntutan pada masing-masing jabatan. c) Aspekaspek Kematangan Karier Super dalam Savickas (2001: 52) mengemukakan empat aspek yang dapat digunakan untuk mengukur kematangan karir remaja, antara lain: (1) Perencanaan yaitu kesadaran individu bahwa dirinya harus membuat pilihan pendidikan dan akrir serta mempersiapkan diri untuk membuat pilihan tersebut. (2) Eksplorasi Yaitu individu secara aktif menggunakan berbagai sumber untuk memperoleh berbagai sumber mengenai dunia kerja umumnya dan untuk memilih salah satu bidang pekerjaan khususnya. (3) Kompetensi Informasional Yaitu kemampuan untuk menggunakan informasi tentang karir yang dimiliki untuk dirinya, serta mulai mengkristalisasikan pilihan pada bidang dan tingkat pekerjaan tertentu. (4) Pengambilan Keputusan Yaitu individu mengetahui apa saja yang harus dipertimbangkan dalam membuat pilihan pekerjaan yang sesuai dengan minat dan kemampuan.

\section{Penerapan Layanan Karier untuk Meningkatkan Kematangan Karier Siswa}

Layanan karier merupakan aspek yang tidak bisa dipisahkan dalam pelaksanaan bimbingan karier, yang dilakukan oleh seorang konselor kepada konseli atau siswa. Dalam pemberian layanan tersebut dengan tujuan untuk membantu siswa memenuhi kebutuhannya. Bentuk layanan yang dapat diberikan berupa layanan informasi karir dan layanan konseling karier.

Karier adalah urutan aktifitas-aktifitas yang berkaitan dengan pekerjaan dan perilaku-perilaku, nilai-nilai dan aspirasi seseorang selama rentang hidup orang tersebut (Simamora, 2001: 505). Siswa SMK difokuskan dengan lulusan yang siap kerja, walaupun pada kenyataannya banyak siswa yang sanggup untuk melanjutkan pendidikan ke jenjang berikutnya yaitu kuliah, akan tetapi siswa SMK cenderung memilih untuk bekerja dengan pekerjaan sesuai standar dan kapasitas lulusan SMK. Hal ini sebenarnya sangat disayangkan karena banyak potensi dan kompetensi yang bisa lebih dikembangkan apabila siswa berkenan melanjutkan pendidikan ke jenjang berikutnya. Untuk itu diperlukan kematangan karier siswa untuk dapat merencanakan, mengeksplor kariernya secara matang, salah satunya melalui layanan karier yang diberikan di sekolah.

Penerapan layanan karier di sekolah diberikan oleh konselor kepada siswanya melalui layanan bimbingan karier. Menurut Winkel (dalam Tohirin, 2015: 201) bimbingan karier merupakan bantuan dalam mempersiapkan diri menghadapi dunia pekerjaan, pemilihan lapangan pekerjaan atau jabatan (profesi) tertentu serta membekali diri agar siap memangku jabatan tersebut dan dalam menyesuaikan diri dengan tuntutan-tuntutan dari lapangan pekerjaan yang dimasukinya. Melalui layanan karier diharapkan siswa SMK mempunyai kematangan karier yang baik sehingga dapat berpikir secara matang dalam merencanakan dan mengambil keputusan kariernya dan dapat meningkatkan taraf hidupnya menjadi lebih baik.

Dari paparan teoritis di atas maka dapat dirumuskan hipotesis penelitian sebagai berikut: Ha: Penerapan layanan karier dapat meningkatkan kematangan karier siswa SMK PGRI Wonoasri Kabupaten Madiun tahun pelajaran 2018-2019, Ho: Penerapan layanan karier kurang dapat meningkatkan kematangan karier siswa SMK PGRI Wonoasri Kabupaten Madiun tahun pelajaran 2018-2019.

\section{METODE PENELITIAN}

Penelitian ini menggunakan metode penelitian eksperimen. Penggunaan metode eksperimen ini didukung pendapat Sugiyono (2012: 107) yang menyatakan bahwa metode eksperimen merupakan metode penelitian yang digunakan untuk mencari pengaruh perlakuan tertentu terhadap yang lain dalam kondisi yang terkendalikan. Desain penelitian menggunakan One Group Pretest-Posttest design, dengan membandingkan keadaan sebelum dan sesudah diberi perlakuan. Desain tersebut dapat digambarkan sebagai berikut:

01 = nilai pretest (sebelum diberi perlakuan)

$01 \times 02$ 02 = nilai posttest (sesudah diberi perlakuan)

(Sugiyono, 2012: 111)

Langkah-langkah dalam penelitian ini meliputi: (1) Pre test, Pemberian pre test berupa angket kematangan karier kepada 8 siswa dengan kematangan karier yang berada pada kategori sangat rendah dengan tujuan untuk melihat tingkat kematangan karier siswa sebelum diberikan 
perlakuan. (2) Pemberian Perlakuan Layanan karier, Pemberian perlakuan layanan karier dalam bentuk layanan klasikal (pemberian materi karier) dan konseling kelompok kepada 8 orang siswa kelas XII. (3) Pemberian Post test, Pemberian post test dengan materi angket kematangan karier yang sama kepada 8 siswa dengan tujuan untuk membandingkan keadaan antara sebelum dan sesudah diberikan perlakuan, dan untuk mengetahui keberhasilan dari penerapan layanan karier untuk meningkatkan kematangan karier siswa yang sudah diberikan.

\section{1) Subyek Penelitian}

Subyek dalam penelitian ini adalah siswa kelas XII Akuntansi SMK PGRI Wonoasri Kabupaten Madiun yang terdiri dari 2 kelas dengan jumlah 49 siswa, dengan teknik purposive random sampling. Teknik purposive random sampling yaitu teknik sampling yang digunakan peneliti jika peneliti mempunyai pertimbangan-pertimbangan tertentu di dalam pengambilan sampelnya atau penentuan sampel untuk tujuan tertentu (Riduwan, 2011: 63). Berikutnya peneliti mengambil 8 siswa yang memiliki tingkat kematangan sangat rendah untuk diberikan perlakuan melalui layanan konseling kelompok.

2) Lokasi Penelitian

Penelitian ini dilaksanakan di kelas XII Akuntansi SMK PGRI Wonoasri Kabupaten Madiun, Tahun Pelajaran 2018-2019.

3) Instrumen Pengumpulan Data

Metode pengumpulan data dalam penelitian ini sesuai dengan dua variabel. yaitu: a) Penerapan Layanan Karier, instrumen pengumpulan data untuk variabel penerapan layanan karier adalah studi dokumentasi melalui pemberian materi karier dan konseling kelompok karier dengan tahap-tahap menurut Edi (2013) sebagai berikut: (1) Tahap Pembentukan Pada tahap ini menerima secara terbuka dan mengucapkan terima kasih, berdoa, konselor menjelaskan pengertian konseling kelompok, konselor menjelaskan tujuan konseling kelompok. (2) Tahap Peralihan Menjelaskan kegiatan konseling kelompok, mengenali, perkenalan, tanya jawab kesiapan anggota. (3) Tahap Kegiatan Menjelaskan kesulitan yang hendaknya dikemukakan oleh anggota, anggota mengemukakan kesulitan, membahas kesulitan secara tuntas, menegaskan komitmen anggota. (4) Tahap Pengakhiran Penegasan bahwa konseling kelompok akan diakhiri, anggota kelompok memberikan kesan dan pesan, pembahasan kegiatan lanjutan, ucapan terima kasih, berdoa. Pemberian materi karier dilakukan sebanyak 2 kali pertemuan dan konseling kelompok karier sebanyak 1 kali pertemuan. b) Kematangan Karier, skala pengukuran kematangan karier yang digunakan pada penelitian ini adalah skala Likert, yaitu skala yang digunakan untuk mengukur sikap, pendapat, persepsi seseorang atau sekelompok tentang kejadian atau gejala sosial (Riduwan, 2011: 87).

4) Teknik Analisis Data

Untuk mengetahui tingkat kematangan karier siswa dalam penelitian ini menggunakan angket kematangan karier. Angket digunakan untuk mengungkap data tentang kematangan karier siswa, dimana dalam angket tersebut menggunakan skala Likert yang setiap itemnya menyajikan empat alternatif jawaban yaitu: Sangat setuju $(\mathrm{SS})=4$, Setuju $(\mathrm{S})=3$, Tidak setuju $(\mathrm{TS})=2$ dan Sangat tidak setuju (TS) $=1$.

5) Uji Hipotesis

Untuk menguji hipotesis, data dianalisis menggunakan metode kuantitatif dengan analisis statistik dengan rumus Standard Kesalahan Perbedaan Mean (t-test) untuk mencari perbedaan mean sebelum dan sesudah diberikan perlakuan. Rumus bangun t-test sebagai berikut:

$$
\mathrm{t}=\mathrm{Mx-My}
$$

\section{Keterangan}

$\mathrm{M}_{\mathrm{X}}=$ Mean dari sampel $\mathrm{X}$

$\mathrm{M}_{\mathrm{y}} \quad=$ Mean dari sampel $\mathrm{Y}$

$\mathrm{SD}_{\mathrm{bM}}=$ Standard Kesalahan Perbedaan Mean

\section{HASIL DAN PEMBAHASAN}

\section{A. Hasil Penelitian}

1) Kondisi Umum Tingkat Kematangan Karier Siswa SMK PGRI Wonoasri

Gambaran umum tingkat kematangan karier siswa diperoleh dari hasil pengukuran angket kematangan karier terhadap 49 siswa kelas XII Akuntansi SMK PGRI Wonoasri Kabupaten Madiun. Data awal digunakan untuk mengetahui tingkat kematangan karier siswa dan dijadikan dasar untuk melihat penerapan layanan karier untuk meningkatkan kematangan karier siswa.

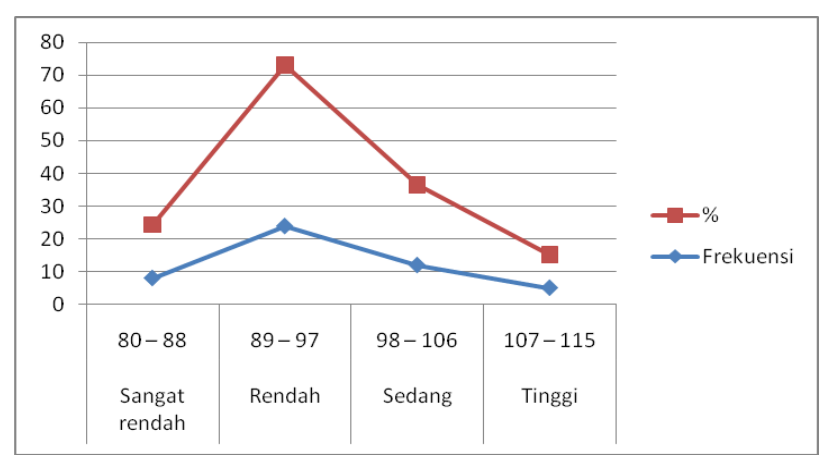

Gambar 1. Grafik Gambaran Umum Tingkat Kematangan Karier Siswa

Berdasarkan hasil data awal terhadap 49 siswa menunjukkan bahwa tingkat kematangan karier yang berada pada kriteria tinggi sejumlah 5 siswa $(10,2 \%)$, tingkat kematangan karier pada kriteria sedang sejumlah 12 siswa 
(24,5\%), tingkat kematangan karier dengan kriteria rendah sejumlah 24 siswa (49\%), dan tingkat kematangan karier dengan kriteria sangat rendah sejumlah 8 siswa (16,3\%). Peneliti menganalisis masih ada siswa yang memiliki tingkat kematangan karier dengan kriteria rendah dan sangat rendah disebabkan masih kurangnya keinginan siswa untuk memikirkan tentang pekerjaan dan kuliah, lebih memilih bekerja karena hanya untuk segera mendapatkan uang.

Dari hasil di atas peneliti mengambil 8 siswa yang memiliki kriteria sangat rendah untuk diberikan perlakuan layanan karier melalui konseling kelompok yaitu dengan tahapan pemberian pre test, perlakuan konseling karier, dan post test.

2) Gambaran Kategori Tingkat Kematangan Karier Siswa SMK PGRI Wonoasri Kabupaten Madiun Sebelum Diberi Layanan Karier (pre test)

Dalam kegiatan pre test ini siswa yang berjumlah 8 orang yang berada pada kriteria sangat rendah diberikan angket kematangan karier untuk mengetahui gambaran kematangan karier siswa sebelum diberikan perlakuan. Tingkat kematangan karier siswa sebelum diterapkan layanan konseling kelompok karier terdapat 8 siswa berada pada kriteria sangat rendah. Hal ini menggambarkan bahwa kematangan karier siswa sebelum diberikan layanan karier masih sangat kurang yang disebabkan kurangnya diberikan motivasi dalam hal pemilihan karier ke jenjang selanjutnya antara keinginan bekerja atau melanjutkan ke jenjang perkuliahan masih belum jelas. Tingkat kematangan karier Pre Test dapat dilihat pada grafik berikut:

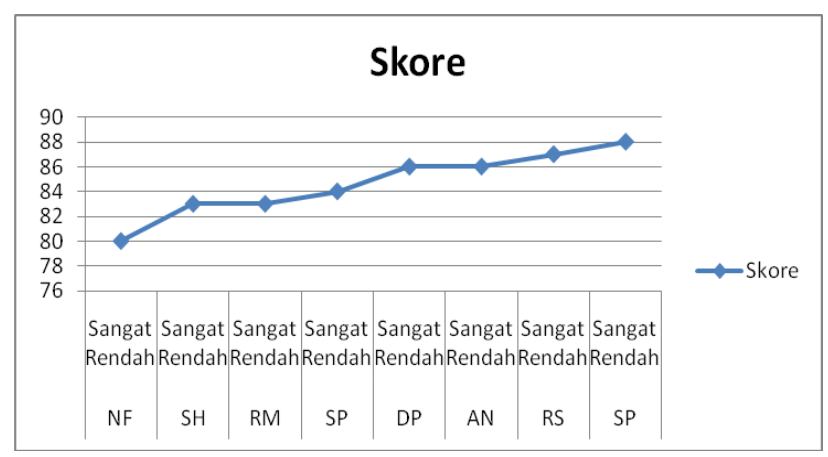

Gambar 2. Grafik Tingkat Kematangan Karier Pre Test

3) Gambaran Kategori Tingkat Kematangan Karier Siswa SMK PGRI Wonoasri Kabupaten Madiun Setelah Diberi Layanan Karier (post test)

Berikut data tentang tingkat kematangan karier siswa sesudah diberi perlakuan layanan konseling kelompok karier, dapat dilihat pada grafik berikut:

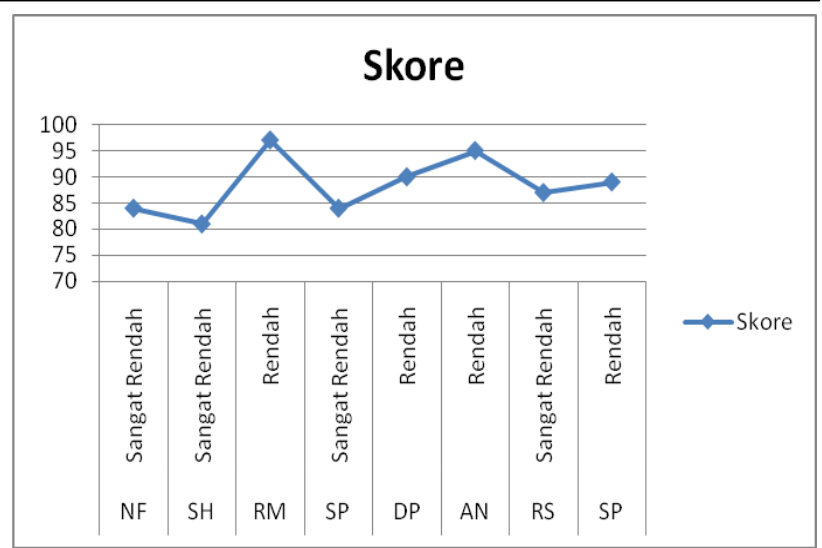

Gambar 3. Grafik Tingkat Kematangan Karier Post Test

4) Perbedaan Tingkat Kematangan Karier Siswa untuk Setiap Subjek Penelitian

Secara rinci dijelaskan perbedaan tingkat kematangan karier siswa pada tahap pre test dan post test, seperti tersaji dalam berikut ini:

Tabel 1. Perbandingan Skor Pre Test dan Post Test

\begin{tabular}{cccccc}
\hline \multirow{2}{*}{ No } & Responden & \multicolumn{2}{c}{ Pre Test } & \multicolumn{2}{c}{ Post Test } \\
\cline { 3 - 6 } 1 & Skor & Kriteria & Skor & Kriteria \\
\hline 2 & SH & 83 & $\begin{array}{c}\text { Sangat } \\
\text { rendah }\end{array}$ & 84 & $\begin{array}{c}\text { Sangat } \\
\text { Rendah }\end{array}$ \\
\hline 3 & RM & 83 & $\begin{array}{c}\text { Sangat } \\
\text { rendah }\end{array}$ & 97 & $\begin{array}{c}\text { Sangat } \\
\text { Rendah }\end{array}$ \\
\hline 4 & SP & 84 & $\begin{array}{c}\text { Sangat } \\
\text { rendah }\end{array}$ & 84 & $\begin{array}{c}\text { Sangat } \\
\text { Rendah }\end{array}$ \\
\hline 5 & DP & 86 & $\begin{array}{c}\text { Sangat } \\
\text { rendah }\end{array}$ & 90 & Rendah \\
\hline 6 & AN & 86 & $\begin{array}{c}\text { Sangat } \\
\text { rendah }\end{array}$ & 95 & Rendah \\
\hline 7 & RS & 87 & $\begin{array}{c}\text { Sangat } \\
\text { rendah }\end{array}$ & 87 & $\begin{array}{c}\text { Sangat } \\
\text { Rendah }\end{array}$ \\
\hline 8 & SP & 88 & $\begin{array}{c}\text { Sangat } \\
\text { rendah }\end{array}$ & 89 & Rendah \\
\hline
\end{tabular}

Tabel diiatas menjelaskan bahwa tingkat kematangan karier siswa setelah diterapkan layanan konseling kelompok karier terdapat 4 siswa berada pada kriteria sangat rendah dan 4 orang berada pada kriteria rendah. Hal ini menggambarkan bahwa terjadi peningkatan tingkat kematangan karier siswa setelah diberikan layanan karier walaupun masih dalam kriteria rendah. Dalam hal ini peningkatan kematangan karier siswa disebabkan yang awalnya beberapa siswa yang berkeinginan untuk melanjutkan ke perguruan tinggi, akan tetapi masih ragu dengan kemampuannya dalam mengikuti perkuliahan, maka sedikit banyak sudah merasa yakin, dan berani mengambil keputusan terhadap pilihan kariernya.

5) Hasil Uji Hipotesis

Untuk menentukan uji beda rata-rata berpasangan menggunakan Paired $\mathrm{T}$ Test dengan program SPSS Statistics 22,0. Didapatkan hasil rata-rata kematangan karier 
siswa sesudah diberikan layanan karier sebesar 88,38 sedangkan sebelum diberikan layanan karier sebesar 84,63. Berdasarkan data diperoleh nilai Sig. (2-tailed), apabila diperoleh perbandingan nilai probabilitas (Sig. 2-tailed) < 0,05 maka H0 ditolak, dan apabila nilai probabilitas (Sig. 2-tailed) $>0.05$ maka $\mathrm{H} 0$ diterima.

Tabel 2. Hasil Uji Beda dengan SPSS 22,0 Paired Samples Statistics

\begin{tabular}{|c|c|c|c|c|c|}
\hline & & Mean & $\mathrm{N}$ & Std. Deviation & $\begin{array}{c}\text { Std. Error } \\
\text { Mean }\end{array}$ \\
\hline \multirow[t]{2}{*}{ Pair 1} & sebelum & 84,63 & 8 & 2,615 & 925 \\
\hline & sesudah & 88,38 & 8 & 5,553 & 1,963 \\
\hline
\end{tabular}

Berdasarkan hipotesis dalam penelitian yang menyatakan penerapan layanan karier dapat meningkatkan kematangan karier siswa dapat dijelaskan dari hasil perhitungan statistik dengan diperoleh nilai t hitung 1,977. Nilai probabilitas sebesar $0,089<0,05$, sehingga dapat dinyatakan $\mathrm{H} 0$ ditolak dan Ha diterima, yang artinya penerapan layanan karir dapat meningkatkan karier siswa, seperti disajikan dalam tabel berikut ini.

Tabel 3. Nilai t hitung data Penelitian

Paired Samples Correlations

\begin{tabular}{|l|r|r|r|}
\hline & N & Correlation & \multicolumn{1}{c|}{ Sig. } \\
\hline Pair 1 sebelum \& sesudah & 8 &, 306 &, 461 \\
\hline
\end{tabular}

Paired Samples Test

\begin{tabular}{|c|c|c|c|c|c|c|c|c|}
\hline & \multicolumn{5}{|c|}{ Paired Difierences } & \multirow[b]{3}{*}{$t$} & \multirow[b]{3}{*}{ of } & \multirow[b]{3}{*}{ Sig. (2-tailed) } \\
\hline & \multirow[b]{2}{*}{ Maаn } & \multirow[b]{2}{*}{ Std. Deviation } & \multirow{2}{*}{$\begin{array}{l}\text { Sid. Error } \\
\text { Mean }\end{array}$} & \multicolumn{2}{|c|}{$\begin{array}{l}\text { 95\% Conididence Interval of the } \\
\text { Difierence }\end{array}$} & & & \\
\hline & & & & Lower & Upper & & & \\
\hline Pail'1 sebelum- sesudah & -3.750 & 5,365 & 1,897 & $-8,235$ & .735 & - 1,977 & 7 & .089 \\
\hline
\end{tabular}

\section{B. Pembahasan}

Kematangan karier menjadi hal yang sangat penting di dalam diri individu, dimana dapat memberikan arah keputusan yang baik bagi individu dalam kariernya di kemudian hari. Menurut Super (dalam Winkel, 2006) Kematangan karier merupakan keberhasilan individu dalam menyelesaikan tugas perkembangan karier yang khas di setiap tahap perkembangan yang ditunjukkan dengan kesesuaian perilaku karir individu dengan perilaku karier yang diharapkan.

Banyak hal yang dapat menjadi hambatan bagi seseorang dalam meningkatkan kematangan karier, diantaranya kurangnya motivasi dalam mencapai kesuksesan, cenderung mengikuti teman atau lingkungannya. Hal ini juga terjadi pada remaja yang sedang berada pada masa transisi seringkali kesulitan dalam menentukan pilihan kariernya. Menurut Super (dalam Suherman, 2013: 78) perkembangan karier remaja berada pada tahap ekplorasi (usia 15-24 tahun) yang ditanda dengan mulai melakukan penelaahan diri, mencoba membagi berbagai peranan, serta melakukan penjelajahan pekerjaan. Pada masa remaja ini pula sering kali terjadi ketidaksiapan yang dapat berakibat pada pengambilan keputusan yang salah atau kurang tepat yang nantinya dapat berdampak pada karier kedepannya. Remaja yang dimaksud dalam penelitian ini adalah siswa SMK cenderung merencanakan kariernya hanya didasarkan pada keinginan dirinya dan mengikuti lingkungannya (teman) tanpa mempertimbangkan kemampuannnya.

Menurut Hornby (dalam Walgito, 2010: 201) karier adalah pekerjaan atau profesi. Pekerjaan akan dilakukan dengan senang hati dan penuh kegembiraan apabila apa yang dilakukan sesuai dengan keadaaan dirinya, kemampuannya, minatnya dan potensi-potensi yang ada pada dirinya. Sehingga orang yang menduduki karier tersebut akan berusaha meningkatkan prestasinya, mengembangkan potensi dirinya, lingkungannya, serta sarana dan prasarana yang diperlukan dalam menunjang perkerjaan yang sedang dijabatnya. Sebaliknya individu tidak akan merasa nyaman apabila pekerjaan yang dilakukannya tidak sesuai dengan dirinya. Layanan karier adalah suatu bantuan yang diberikan konselor kepada siswa agar dapat merencanakan, mengeksplor dan mengambil keputusan kariernya sesuai potensi dan kemampuannya. Melalui layanan karier siswa diarahkan kepada pilihan kariernya dengan tepat sesuai kemampuan yang dimiliki, siswa juga diarahkan kepada pengambilan keputusan kariernya secara tanggung jawab.

Tujuan penelitian ini adalah untuk (1) mengetahui tingkat kematangan karier siswa SMK PGRI Wonoasri Kabupaten Madiun tahun pelajaran 2018 - 2019, dan (2) mengetahui sejauh mana penerapan layanan karier dapat meningkatkan kematangan karier siswa SMK PGRI Wonoasri Kabupaten Madiun tahun pelajaran 2018 - 2019?

Berdasarkan hasil penelitian diketahui skor mean sebelum diberikan intervensi melalui penerapan layanan karier sejumlah 84,63, dan skor mean setelah diberikan penerapan layanan karier menjadi 88,38, sehingga dapat disimpulkan terjadi peningkatan tingkat kematangan karier siswa melalui penerapan layanan karier.

\section{SIMPULAN DAN SARAN}

\section{A. Simpulan}

Berdasarkan analisis data penelitian, maka dapat disimpulkan sebagai berikut: (1) Adanya peningkatan kematangan karier siswa melalui penerapan layanan karier sejumlah 3,75 \%. Hal ini dapat diketahu dari skor mean sebelum diberikan perlakuan sejumlah 84,63 dan sesudah diberikan perlakuan sejumlah 88,38. (2) Penerapan layanan karier efektif dalam meningkatkan kematangan karier siswa SMK PGRI Wonoasri Kabupaten Madiun.

\section{B. Saran}

Bertolak dari simpulan sebagaimana telah dijelaskan di atas maka dikemukakan saran-saran sebagai berikut: (1) Sekolah disarankan kepada pihak sekolah bekerja sama dengan staf sekolah untuk ikut membantu para siswa dengan 
senantiasa menumbuhkan kesadaran dan kematangan diri, baik di lingkungan di sekolah maupun di luar lingkungan sekolah. Cara yang dapat ditempuh adalah dengan mengoptimalkan layanan bimbingan dan pembelajaran kepada siswa, baik yang dilakukan oleh para guru, tenaga bimbingan. Jika diperlukan dapat mengikutsertakan orang tua siswa dan tokohtokoh pendidikan yang berada di masyarakat. (2) Para Guru disarankan kepada para guru (staf pengajar)ketika mengampu mata pelajaran untuk senantiasa membantu menumbuhkan dan meningkatkan rasa percaya diri dan mengembangkan kematangan diri siswa, khususnya kematangan karir. Harapannya adalah dalam diri siswa timbul pemahaman tentang dirinya sendiri maupun tentang dunia kerja, dengan segala aspeknya. (3) Konselor disarankan kepada konselor sekolah (petugas bimbingan) hendaknya mengintensifkan program layanan bimbingan dan konseling di sekolah, yang salah satu komponen programnya menyangkut layanan bimbingan karir. Melalui program layanan bimbingan dan konseling pada umumnya bagi para maka siswa akan memperoleh dasar-dasar memahami dirinya sendiri dan lebih khusus memiliki pemahaman dan penghayatan tentang dunia kerja.

\section{DAFTAR RUJUKAN}

Arikunto, S. 2010. Prosedur Penelitian Suatu Pendekatan Praktek Edisi Revisi Jakarta: Rineka Cipta.

Atli, A. 2017. Five Factor Personality Traits as Predictor of Career Maturity. EurasianJournal of Educational Research (EJER). 17(68):153$167 \cdot$ March 2017 with 463 Reads

Edi, M.K. 2013. Konseling Kelompok. Bandung: Penerbit Alfabeta.

Ekaningrum, I.F. 2002. The Boundaryless Career in the 21st Century, Journal of Vision (Management Economics and Accounting Studies). Vol. IX, No.1 February 2002, FE Unika Soegijapranata Semarang.

Nurihsan, J.A. 2005. Strategi Layanan Bimbingan dan Konseling. Bandung: Refika Aditama.
Patton, W \& Creed, P.A. 2002. The Relationship Between Career Maturity and Work Commitmnet in a Sample of Australian High School Students. Jurnal of Career Development, Vol.29, No.2. Queensland University of Technology. Desember 2002.

Poerwadarminta, W.J.S. 1996. Kamus Umum Bahasa Indonesia. Jakarta: PN Balai Pustaka.

Riduwan. 2011. Belajar Mudah Penelitian. GuruKaryawan Peneliti Pemula. Bandung: Alfabeta

Satori, Djam'an dan Aan K. 2012. Metodologi Penelitian Kualitatif. Bandung: Alfabeta.

Savickas, Mark L. (2005). The theory and practice of career construction. In S. D. Brown \& R. W. Lent (Eds.), Career development and counseling: Putting theory and research to work (pp. 4270). Hoboken, NJ: John Wiley \& Sons

Simamora, H. 2001. Human Resource Management, STIE YKPN Publisher, Yogyakarta.

Sugiyono, 2012. Metode Penelitian Pendidikan, Pendekatan Kuantitatif, Kualitatif, dan R \& D. Bandung: CV Alphabeta.

Suherman, U. 2013. Bimbingan dan Konseling Karir: Sepanjang Rentang Kehidupan. Bandung: Rizqi Press.

Sukardi, D.K. 1987. Bimbingan Karir di Sekolahsekolah. Jakarta: Ghalia Indonesia.

Tohirin. 2015, Bimbingan dan Konseling di Sekolah dan Madrasah (berbasis Integrasi). Jakarta: PT. RajaGrafindo Persada.

Walgito, B. 2010. Bimbingan dan Konseling (Studi \& Karier). Yogyakarta: Andi.

Winkel dan Sri H. 2006. Bimbingan dan Konseling di Institusi Pendidikan. Yogyakarta: Media Abadi. 